\title{
Exploring the Migrant Experience in Small Business Activities in Auckland: A Case Study of African Migrants
}

\author{
Olufemi Muibi Omisakin ${ }^{1}$, Camille Nakhid $^{2}$, Romie Littrell $^{3} \&$ Jane Verbitsky $^{2}$ \\ ${ }^{1}$ Auckland University of Technology, New Zealand \\ ${ }^{2}$ Auckland University of Technology, Faculty of Culture and Society, School of social sciences and Public policy, \\ New Zealand \\ ${ }^{3}$ Auckland University of Technology, Faculty of Law and Business, Department of International Business, New \\ Zealand
}

Correspondence: Olufemi Muibi Omisakin, Auckland University of Technology, New Zealand. E-mail: olufemiomisakin@yahoo.com

Received: June 19, 2015

Accepted: July 14, 2015

Online Published: July 15, 2015

doi:10.5430/jbar.v4n2p9

URL: http://dx.doi.org/10.5430/jbar.v4n2p9

\begin{abstract}
This qualitative study seeks to enrich the understanding of migrants' perceived experience in running small businesses in Auckland, New Zealand. The study will also examine what motivated migrants into business, their experiences in labour market as well as the challenges they faced in running a business. The study focuses on African migrant small business owners excluding South Africans as this population has been extensively researched and documented (Meares et al., 2011; Warren, 2003). The theoretical foundation of the study rests on labour disadvantage and cultural theories. In-depth open ended face-to face interviews between 11-20 participants selected through purposive sampling will be used to collect data. Thematic analysis will be used to analyse data collected.
\end{abstract}

Keywords: African Migrants, Migrant business, Small business, Small business entrepreneurs, Self-employed

\section{Introduction}

Migration has been a recurrent phenomenon since the beginning of human existence involving search for a better life. Recently migrating has been identified as a major factor for facilitating economic growth and development. Most developed economy often source for skilled migrant to help develop their economy especially countries with aging population and skilled labour shortage. However people will naturally migrate for economic, political, and social factors this is because every individual would want to live where there are economic prosperities, peace with guaranteed political rights and where he or she can be socially responsible. This explains why Africans migrants would illegally cross the Mediterranean to the Europe Union despite all odds. However, irrespective of the mode used by migrant to migrate they have always been great contributor to the economic development of their host country either by picking up skilled job, unskilled job or establishing small business for sustenance and performing their social responsibilities.

Traditionally New Zealand has been a popular destination for migrants but until recently there has not been much African in New Zealand. The adoption of a formal refugee quota in 1987 by New Zealand, and followed by outbreak of wars, famine and political unrest in some African countries, like Ethiopia, Somalia, Rwanda enabled New Zealand to give asylum to sizable number of Africans from these troubled countries starting from the early 90 's.

Often migrants are positive that all will be well when they arrive at their destination but they are mostly face with social and economic challenges. To overcome these unexpected challenges they engage in small business activities refer to as "migrant business" for empowerment against poverty.

A number of studies have been carried out on the motivations for migrant and ethnic entrepreneurship (Baycan-Levent. \& Kundak, 2009; Domboka., 2013; Franck., 2012; Liargovas. \& Skandalis, 2012; Masurel, Nijkamp, Tastan, \& Vindigni, 2002; Whitehead., Purdy, \& Mascarenhas-keyes, 2003). Most of these studies indicates that Asian migrant business owners dominate migrant small business in Auckland (Cain., Meares, Spoonley, \& Peace, 2011; de Vries, 2012). The literature review shows a dearth of knowledge concerning the experience of 
migrants in job search and small business activities in New Zealand, particularly in the case of African migrants, there exists a gap in the literature in this area.

Therefore, to bridge the identified research gap in the literature, this study will investigate the job search experiences of African migrants residing in Auckland before they became business owners, their experience in running small business, what motivated them into business as well as the challenges they faced in setting up a business and running it.

\subsection{Research objective}

The objective of this study is to explore African migrants' experience in small businesses in Auckland. Specifically, the objectives set out for this study include:

- To examine the experiences that African migrants have had in the labour market;

- To investigate the motivations of African migrants for moving into small business activities in Auckland;

- To examine the challenges faced by African migrant small business owners in running small businesses and how such challenges were overcome.

\subsection{Research question}

The main research question is:

\section{How do African migrants perceive their experience of small business activities in Auckland?}

The subsidiary questions include:

- What experiences do African migrants have with the labour market?

- What motivates African migrants into small business activities in Auckland?

- What are the challenges encountered by African migrants setting up small businesses?

- How do they overcome the challenges?

\subsection{Limitation of the study}

I have chosen to explore African migrants' experience in small business activities in Auckland because there has so far been no study or documentation in this area in any area of New Zealand. I have chosen Auckland as the city in which to focus the study because it is the largest city in New Zealand and houses more than three quarters of New Zealand's African population.

African small business owners from any country in Africa excluding South Africa will be recruited as participants for this study. Small business owners from South Africa will be excluded because there has already been a number of studies on South African small business enterprises in New Zealand while migrants from other African countries who operate small businesses have not been studied.

\section{Literature review}

International migration, migration across national borders, has become a key feature of modern society in both developed and developing countries. International migrants are people crossing national borders with the intention to settle in another country for a period of 12 months or longer (Philip., 2001; Sasse. \& Thielemann, 2005). This trend has become a key feature in modern societies (Gorter, Nijkamp, \& Poot, 1998).

Migrating across borders is influenced by a combination of economic, political and social factors - either in a migrant's country of origin or in the country of destination (Baycan-Levent \& Nijkamp, 2009). Boyd (1989) argued that structural forces are the basic motivational influence for international migration, and are viewed as a combination of systemic unemployment, war, political, economic and social unrest in the migrant sending country and perceived good employment, political, economic and social prospects in the migrant-receiving country (Massey et al., 1994). A high number of people continue to migrate from countries where they think their hope and aspirations cannot be met. This trend will continue as long as migrant-sending countries do not improve upon the push factors mentioned earlier. For instance, the International Organisation for Migration (2014) reported that for the reasons of war, hopelessness and political instability in most African countries 220,194 migrants crossed the Mediterranean Sea to the European Union illegally in 2014. This figure represented an increase of $266 \%$ compared to 2013. Daniels, Radebaugh and Sullivan (2002) submitted that, in 2002, there were over 150 million international migrants worldwide and that immigration provided a good source of linkage among nations. The United Nations estimated that there were about 214 million international migrants worldwide in 2010 and projected that this number could 
increase to 405 million by the year 2050. The United Nations Report (2010) pointed to a consistent rise in the number of migrants from developing countries as a result of consistent and spontaneous political, economic, and social crises. Sometimes this included outright war, especially in Africa, some parts of Asia and the Middle East.

Some migrants are full of economic hope and enthusiasm before migrating; thinking that all will be well when they arrive at their destination. In most cases, they are unable to meet their expectations as they are faced with structural and cultural problems in the form of social exclusion, discrimination, unemployment, and lack of expected local values and skills (Baycan-Levent \& Nijkamp, 2009). Often, migrants are unable to secure their desired jobs or they face discrimination.

Faced with social and economic challenges in their new abode, migrants engage in various economic activities to empower themselves against unemployment and poverty (Baycan-Levent \& Nijkamp, 2009). Metcalf (1996) found that engaging in business start-up activities is a popular means by which migrants solve the problem of unemployment. Modood and Virdee (1996) concluded that migrants are influenced by three factors when deciding to set up businesses - namely: economic opportunity, cultural affiliations and reaction to their inability to secure meaningful jobs.

In this study, migrant business refers to business activities undertaken by migrants from a specific socio-cultural and ethnic background or country of origin (Sahin, Nijkamp, \& Reietdijk, 2009). Migrant business differs from mainstream business in that it is oriented towards migrant products and the migrant market (Choenni., 1997). Migrant businesses play a prominent role in the host country as they employ both migrants and non-migrants, thereby contributing to economic growth and the resolution of social problems (Baycan-Levent \& Nijkamp, 2009). However, migrants often encounter different and challenging experiences before becoming migrant business owners, with some being discriminated against and told that they lack host country work experience (Min \& Bozorgmehr, 2003). Thus, self-employment is frequently an important aspect of the immigrant experience in the host country labour market (Borjas., 1986).

Globally, migrant businesses contribute economically and socially to both the migrants and the host society in terms of job provision and income generation for the economy, and to the government in the form of taxes. Studies have shown the immense contributions made by migrants and their businesses to the economic growth of their host countries. For example, the American Community of Survey (2010) established that $18 \%$ of small businesses in the United States (US) are owned by migrants, while in the United Kingdom (UK) ethnic minority businesses account for $9.8 \%$ of small businesses (Mascarenhas-Keys, 2003).

Migrant businesses represent a large and growing share of the labour force in most developed countries in Europe and the US. The contribution of migrant businesses to these countries is in fact overwhelming. For instance, in 2005 Asian-owned migrant enterprises in the UK provided 300,000 jobs with a total turnover of 60 billion pounds (London, 2005). Despite this contribution, host countries have adopted several measures to control the influx of migrants as it is widely held that migrants are taking jobs from the country's residents. In June 2008, the European Union (EU) Parliament adopted a directive for the deportation of unauthorised migrants in the EU to their countries of origin. Observers interpreted this as a response by EU leaders to the growing economic crisis and unemployment in the EU (Acosta, 2009).

Between 2002 and 2007 in the US, immigrant businesses generated US \$67 billion. Immigrant business owners accounted for one-quarter of the business income in California, New York, Florida and New Jersey (Fairlie, 2008). However, towards the end of 2007, the US was confronted with a financial crisis which led the US into recession with disruptions in the flow of credit to business and consumers (Allen \& Carletti, 2009). However, at the same time, migrant business continued to perform well. In Canada, small/minority-owned businesses accounted for 39\% of Canada's GDP and accounted for 31\% of Canada's exports valued at US\$80 billion (Canada, 2011). The growth trends of migrant business are global and they are expected to continue.

However, while migrants are contributing to their host countries, the families of migrants in the home countries also benefit from migrants through remittances and direct investment back into the home countries (Nwajiuba., 2007). The author submitted that between 2001 and 2006 Ghanaian migrants remitted a total sum of US $\$ 5$ billion to Ghana. Remittances to migrant families often help improve their standard of living, and access to health and schooling. The World Bank (2014) reported that global remittances in 2014 were US\$582 billion and out of this over US\$404 billion went to developing countries, a figure that is estimated to reach US\$454 billion by the end of 2015. Overall, The World Bank projected that global remittances could reach \$US608 billion by the end of 2015. This data indicates that there has been an unprecedented level of cross-border migration and migration within countries. 
Undoubtedly, this has generated significant socio-economic gains for the host countries as well as the migrants' families who remain within the countries of origin.

\subsection{Immigrants in New Zealand}

As a settler society, New Zealand is founded on immigration, and it is regarded as a popular destination for migrants. European immigrants are the first migrants to New Zealand (Erica, 2013). In recent times, New Zealand has attracted immigrants from all over the world, and Auckland has the highest concentration of immigrants in New Zealand (Statistics New Zealand, 2013). The 2013 census report indicates that New Zealand's ethnic make-up has changed considerably compared to previous head counts. However, those of European descent remain the largest of the major ethnic groups at 2, 969, 391 people (74\%). The second largest ethnic group is Maori at 598, 605 people (14.9\%). Asians make up the third largest ethnic group with a population of 471, $711(11.8 \%)$. The fourth largest ethnic group is Pacific people with a total population of 295, 944 (7\%). Middle Eastern, Latin American and African groups constitute only 46, 953 people (1.2\%). However, New Zealand is referred to as a multi-cultural society and it is easy to see people of different ethnic nationalities in most major cities of New Zealand.

Auckland has a population of 1.42 million people and is described as New Zealand's multicultural gateway (Statistics New Zealand, 2014). The Auckland population has the highest number of overseas-born residents (40\%) in New Zealand, with the majority of those being Asian (23.1\%) (Statistics New Zealand, 2013). The concentration of migrants in Auckland can be justified because it is the economic nerve centre of the country and, therefore, provides migrants with the opportunity to make easy contacts concerning employment or business. According to Masurel et al. (2004), migrants prefer to settle in cities where they feel it is easier to secure employment or start a business

This has had a positive impact on the Auckland economy particularly in the area of migrant business establishment (Cain. et al., 2011). In New Zealand, migrant businesses are very prominent in the economy and have made New Zealand a more tolerant society, one that reflects the wider diversity of values held by the rest of the world (Yeabsley, 1997).

In the late $80 \mathrm{~s}$ and early $90 \mathrm{~s}$, African migrants in New Zealand were mostly refugees from Ethiopia, Somalia, Zimbabwe, the Democratic Republic of Congo, Uganda, Rwanda, Eritrea, Djibouti and Sudan. Groups of immigrants from these countries migrated to New Zealand for similar reasons: political instability, persecution by government, war, famine and a sense of hopelessness. Most of them settled in Auckland while smaller numbers went to Wellington and Christchurch. At the same time, African migrants from other African countries emigrated as professionals under the skilled migrant category and were granted permanent residence on arrival or after securing a skilled job. Others came as students, and after completing their studies, they secured jobs and were granted residence.

Migrants have provided New Zealand with new sources of cultural knowledge and language skills, promoted tourism and strengthened external links. Migrants' personal networks have contributed greatly to the New Zealand economy by attracting foreign investment and promoting trade with other countries (Morgan, 2002).

\section{Theoretical Perspective}

Several theories can be employed to investigate migrants' business opportunities and cognitive processes in decision-making. The most prominent are opportunity structure theory, middleman minority theory, ethnic enclave theory, cultural theory and labour disadvantage theory (Bonacich., 1973; Lee, 2003; Masurel. et al., 2004; Volery., 2007). These theories have been employed when exploring migrant businesses over the years. Literature reviews indicate that labour disadvantage theory and cultural theory appear to be most widely used in the study of migrant business. Given this, the researcher proposes to adopt labour disadvantage and cultural theories for this study.

\subsection{Labour disadvantage theory}

Labour disadvantage theory is referred to as "blocked mobility theory" (Li., 1997). Li further argues that migrants are mostly pushed into self-employment because of the difficulties they encounter participating in the host country labour market. These difficulties may include language barriers, racial discrimination and lack of work experience in the host country, as well as immigration policy and non-recognition of educational and professional experience from the migrants' country of origin. As a result, the only means of economic survival that may be left for migrants is to start up a small business (Min \& Bozorgmehr, 2003).

Labour disadvantage theory is a proven framework that provides an insight into migrants' motivational experiences before business start-up as well as involvement in business activities, and it has been widely used in the migrant 
business literature (Li, 1997; Mata \& Pendakur, 1999; Schmis, 2013; Waldinger et al., 1990). Volery (2007) argued that migrants in businesses are not necessarily a sign of success, but an alternative to unemployment and a means of sustenance.

Volery's view affirmed research findings in Europe, North America and Australia, where immigrants face a great deal of discrimination (Light, 1979; Min \& Bozorgmehr, 2000). In his study of the US, de Raijman (1996) found that Koreans, South Asians and Middle Eastern people are more likely to experience labour discrimination than white natives because of their obvious differences and easily identifiable origins. The author concluded by citing African-Americans and Mexicans as the most labour disadvantaged ethnic minorities in the US.

A similar study carried out in New Zealand found that migrants experienced discrimination in the labour market as employers often turn migrants away, saying they lack New Zealand work experience (Butcher, Spoonley, \& Trlin, 2006). By doing this, employers fail to realise that migrants cannot buy experience, but must acquire it by being given an opportunity to experience employment.

Schmis (2013) found that Vietnamese migrants in Germany became self-employed as a reaction to the negative experiences they had in the restricted German labour market. Mata and Pendakur (1999) showed that migrants enter into self-employment because of discrimination experienced in the labour market and disadvantages associated with language proficiency. Li (1997) concluded that labour disadvantages in Canada led migrants towards starting their businesses. Waldinger et al. (1990) identified the migrant experience of only low-paid jobs and discrimination as principal factors that compel migrants to self-employment. Migrant small business owners often face challenging experiences in business management and finance (Collins, 2003; Gaskill, Auken, Howard, \& Manning, 1993; Morrison \& Moir, 1998; Ram \& Deakins, 1996).

\subsection{Cultural theory}

Hoftstede (1991, p. 5) defines culture as "a collective programming of the mind which distinguishes the member of one group or category of people from another." Culture is regarded as a collective phenomenon that is shaped by an individual's social environment.

Immigrant scholars have highlighted the impact of culture on entrepreneurship. They emphasise cultural values like hard work, the involvement of family members, religious ties and trust as the primary source of some immigrant cultural groups' success in business (Bonacich, 1973; Waldinger et al., 1990). Bonacich claimed that immigrant Armenians, Chinese, East African Asians and Jews become entrepreneurs and occupied intermediate positions wherever they migrated because they possess a culture of entrepreneurship.

Masurel et al., (2004) believed that ethnic and immigrant groups possess culturally determined features such as dedication and hard work, belonging to the same strong ethnic or migrant group, economical living, taking and accepting risk, conforming with social value patterns, solidarity and loyalty, and working towards self-employment. These characteristics serve as a resource that can facilitate support and motivate ethnic or migrant self-employment (Fregetto, 2004). Hoselitz (1964) argued that cultural characteristics such as religious beliefs, family ties, work ethics, and compliance with social values serve as ethnic resources, which partially explain the orientation of immigrants towards business. Waldinger (1990) argued that differences in ethnic resources could be used to explain differences in the rate of self-employment between various migrant and ethnic groups.

Volery (2007) concluded that cultural aspects are mostly used to explain the high propensity of Asian people to generate self-employment. Leung (2002) explored factors that made the Chinese successful in the catering business in the United Kingdom and concluded that cultural values and family structure were the contributing factors for Chinese success. However, this assumption failed to consider other critical factors such as employment alternatives, immigration policies, market conditions, government legislation, and the availability of capital (Jones, McEvoy, \& McGoldrick, 2002; Okonta \& Pandya, 2007). Cultural theory emphasises that ethnic cultural resources help immigrants in their business start-up as well as the sustainability of their businesses in their host country (Teixeira, 2001). Li 1993, Basu \& Gowsami (1999), and Teixeira (2001) conclude that certain cultural values such as being industrious, hardworking, saving, reinvesting business earnings, using underpaid or unpaid family labour and ethnic community networks support immigrant entrepreneurs to cut costs, as well as grow and sustain their businesses.

However, the researcher has decided to use labour disadvantage theory because of his belief that the theory will provide important insights into migrant experiences with job searches in the labour market. Findings from the study will be used to explain migrants' inability to secure jobs in the labour market and the effect of this on the sustenance of migrants. Cultural theory will help explain the effects of cultural factors on African migrant business. Using these two theories will help to realise the objectives of the study, which are: exploring African migrant experiences in 
small business activities in Auckland; examining the experiences of African migrants in the labour market; investigating the motivational factors for African migrants into small business; and examining the challenges faced by African migrant small business owners when running a small business.

\section{Method of data collection}

The methods of data collection in this study will be employed under the umbrella of interpretive case study research. Case study research examines a phenomenon using one or more methods of data collection such as interviews, documentary reviews, archival records, direct observation, participant observation and field notes (Yin, 1994).

Myers (2008) argues that case study research in business-related studies uses empirical evidence from the group or organization studied in an attempt to research the subject matter in context. Multiple sources of evidence are used, although most evidence comes from interviews, document, observation and field note taking (Myers, 2009).

Interview methods will be substantially used for data collection. A document review will play a crucial role in case study research because it forms a rich source of evidence to complement interviews. Documents can take the form of letters, internal memos, reports, newspaper articles and so on. For this type of study, it might be difficult for the researcher to obtain business documents from participants.

Observation is a research approach in itself. There are two general types: direct and participant observation. Businesses recommended through snowball sampling techniques will be visited covertly to negotiate inclusion in the study. The visit will include direct observation of each business. This will give the researcher an opportunity to assess whether the recommended businesses meet the study's participant selection criteria, which emphasises that the owner must be an African migrant, and the business must be of African value. The researcher will do this to obtain more information to augment other information sources such as documents and interviews.

Field notes of the visits to business premises will be made to identify the location, age group and ethnic backgrounds of owners, as well as the number of staff employed and customer profiles. The researcher will compare the field notes taken during visits to notes taken during and after the main interview. This will enable the researcher to build a rich description of each participating business.

\subsection{Interviews}

The interview technique is preferred in interpretive studies because it is considered an effective way of accessing and interpreting information from participants (Myers \& Newman, 2007). The researcher will interview participants because it will help elicit information about migrants' perceived experiences in business activities and their motivation to set up businesses in Auckland, New Zealand (Bryman, 2008). To attain the desired goal of this study, the interviewer will make use of semi-structured interviews.

\subsection{Semi-structured interviews}

A semi-structured interview is a qualitative method of inquiry with the use of predetermined sets of open-ended questions by the interviewer that are meant to extract opinions and ideas from the participants about the topic at hand (Saunders et al., 2009).

The researcher will design a semi-structured, open-ended interview question schedule about the experiences of migrant business start-ups as well as running businesses, integration processes, motivational factors into business, factors that have helped migrant commercial success and factors that have held it back. Questions will aim to extract migrant experiences, decisions, ideas, opinions and suggestions about the topic questions discussed (Bryman., 2009).

While interviewing, I will act as the interviewer for the interview sessions because of my familiarity with research problems and questions. This will enhance my ability to respond when an interviewee seeks clarification about particular issues pertinent to the research. The researcher will be able to probe sensitive issues if necessary. However, I intend to assume a minimal role. The researcher will avoid interrupting participants' responses at any point in time except when clarification is needed for particular issues.

While conducting the interviews, I will use a tape recorder to record interviewees' responses to the interview questions. I will also write observation notes about the interview. Thus, the participant will know I care a lot about what she/he is saying and it will also give me the opportunity to record in writing my observations about the interview, especially any non-verbal communication by the participant that cannot be recorded on tape (Bernard \& Ryan, 2010; Denscombe., 1998).

In this particular study area, there are no institutions such as African migrants' business associations in Auckland to provide a survey population. Likewise, there is no data from the Ministry of Economic Development detailing the 
number of African migrant business owners in Auckland. Therefore, it will be difficult for the researcher to estimate accurately the number of African migrant businesses in Auckland. In this type of scenario, the researcher can employ a purposive method in the selection of participants (Grinnell \& Unrau, 2005). Therefore, purposive sampling is proposed for this study because it allows the selection of participants on the basis of the participants' knowledge of the research problem (Grinnell \& Unrau, 2005).

The sample for this study will comprise 15-20 participants who are African migrant small business entrepreneurs in Auckland. The participants will be African migrant business owners. It is expected that 15-20 participants will provide the information needed to comprehensively answer the research questions and provide an arena for further studies. However, the researcher will stop further interviews when there is indication that we have attained saturation.

In this study, the initial approach to known networks will be explored. For example, access to some migrant community associations has been secured. Such associations as the African Communities Forum Inc. (ACOFI) Auckland, Association of Nigerians in New Zealand, Ghanaian Association of New Zealand, Ethiopian Community of Auckland and the Zimbabwean Association of New Zealand have approved visits to association meetings where the research will be advertised and participants solicited. These initial contacts will then introduce the researcher and the research to members who are willing to participate in the research interviews.

Selection will be based on the following criteria:

- The migrant business must be domiciled in Auckland.

- The business must have operated for one to ten years.

- The business owner must be willing to participate in the study.

- A participant must have a relationship with the research problem that is, must be involved in African migrant small business activities in Auckland, New Zealand.

- A participant must be able to speak English and be able to answer questions in English.

\section{Data analysis}

Data in this study will take the form of interview transcripts collected from research participants that reflect experientially on African migrant small business activities and motivations for engaging with business in Auckland.

Thematic analysis will be used to analyse data collected. Anderson (2007) argues that thematic analysis is the most foundational of qualitative analytic procedures because of its informed objectivity or objective epistemological stance. Thematic analysis is a search for themes that emerge as being important to the description of the phenomenon under study (Daly, Kellehear, \& Gliksman, 1997). Thematic analysis is defined as a process of identifying, analysing, and organising themes from the data collected. To establish this, the researcher will carefully read and re-read the data collected (Rice \& Ezzy, 1999).

Thematic analysis requires more involvement and interpretation from the researcher. It moves beyond counting explicit words or phrases and focuses on identifying and describing both explicit and implicit ideas within the data (the themes). Codes will be developed to represent the identified themes linked to raw data for later analysis in response to the research questions.

The researcher coding process would involve recognizing an important moment from the collected data and encoding it prior to a process of interpretation (Boyatzis, 1998). I will ensure that I capture good codes from the data. Boyatzis (Boyatzis, 1998, p. 1) defines a "good code" as one that captures the qualitative richness of the phenomenon. Encoding the information will assist the researcher to organise the datasets to identify and develop themes. The researcher will ensure that data analysis is driven by the primary objective of representing the subjective viewpoint of African migrant small business owners who shared their experiences and their perceptions of involvement in business activities.

This study proposes to adopt Braun and Clarke's (2006) six phases of thematic analysis:

- Becoming familiar with the data collected:

- Generating initial codes:

- Searching for themes:

- Reviewing themes:

- Defining and naming themes: 
- Writing up:

Handling qualitative data analysis manually as discussed above could be stressful for the researcher (Richards, 2000) because of its comprehensiveness and time-consuming nature, particularly where the dataset is huge. Given this Pope, Ziebland and May (2000) recommended the use of software packages for the researcher to explore textual data inductively using thematic analysis to generate nodes, codes, categories and explanation.

Burnard, Gill, Treasure and Chadwick (2008) argue that there are several computer-assisted qualitative data analysis software (CAQDAS) packages available to help researchers in the analysis of qualitative data. Most common among them are Atlas and NVivo. Atlas belongs to the genre of CAQDAS programs (Friese, 2014). NVivo is a software package to aid qualitative data analysis designed by QSR International.

This study will employ the NVivo software package for its data analysis. Using NVivo package will help me to manage, sort and organize volumes of my data, store, annotate and retrieve text, locate words and extract quotes. The NVivo package will also make data process easier for me because of its flexibility, accuracy, transparency, and will provide me with a general picture of data collected (Richards. \& Richards, 1994).

The recorded interviews will be transcribed into Microsoft Word. I will then import same into the NVivo software and start the analysis. NVivo will be able to create codes and nodes from the words that are loaded into the programme. Coding is an essential part of thematic and content analysis because it allows data to be organized into meaningful groups (Braun \& Clarke, 2006). From the codes created, themes will be developed from the answer to the interview questions. I will compare the relationship between themes and find out how the topics created fit into the data collected. A theme is a clustering of categories that contain similar meaning from the data (Braun \& Clarke, 2006). Finally, I will prepare an analytical report from the themes and quotes generated by NVivo.

Despite the importance of computer-assisted software to any researcher carrying out qualitative data analysis, some schools of thought have criticised the use of computer-assisted software by the researcher. Burnard, Gill, Treasure and Chadwick observed that computer-assisted software is merely an instrument, as good or as bad as the researcher who is using it as it does not have an analysis function. Using computer assisted qualitative data analysis could also serve to distance the researcher from the data (Friese, 2014).

Having completed the above-discussed phases of thematic analysis by determining outcomes, the researcher will make conclusions based on the major identified themes in the order of research questions. I will discuss the relationship of the research findings to the literature while answering the research questions. Finally, I will make a summary of the conclusions, followed by recommendations for future research.

I am of the opinion that findings from this study will help the New Zealand government and other government institutions to create policies, strategies and guidelines that will help African migrant business owners as well as other migrant business owners that may have challenges running their companies. Findings from this study will also serve as a reference point for the intending migrant small business owner as well as migrant business scholars. The research report will be helpful to African migrant business associations and African communities that are concerned with business, settlement and integration.

\section{References}

Acosta, D. (2009). Human Rights \& Humantarian Law. European Journal of Migration and Law, 11(1), 19-39. http://dx.doi.org/10.1163/157181609X410575

Allen, F., \& Carletti, E. (2009). The Global Financial Crisis: Causes and Consequences. University of Pennsylvania and European University Institute.

Anderson, R. (2007). Thematic Content Analysis (TCA) Descriptive Presentation of Qualitative Data. Institute of Transpersonal Psychology www.itp.edu www.wellknowingconsulting.org accessed online 16/01/2015.

Basu., A., \& Goswami, A. (1999). South Asian entrepreneurship in Great Britain: factors influencing growth. International journal of entrepreneurial behaviour \& Research, 5(5), 251-275. http://dx.doi.org/10.1108/13552559910300381

Baycan-Levent, \& Nijkamp, P. (2009). Characteristics of Migrant entrepreneurship in Europe. Entrepreneurship \& Regional Development, 21(4), 375-397. http://dx.doi.org/10.1080/08985620903020060

Baycan-Levent., T., \& Kundak, s. (2009). Motivation and driving forces of Turkish entrepreneurs in Switzerland. The European Journal of Social Science Research,, 22(3), 283-308. http://dx.doi.org/10.1080/13511610903383710 
Bernard, H. R., \& Ryan, G. W. (2010). Analyzing Qualitative Data: Systematic Approaches. Los Angeles: SAGE Publications, Inc.

Bonacich., E. (1973). "A theory of middleman minorities,". American Sociological Review, 38, 583-594. http://dx.doi.org/10.2307/2094409

Borjas., G. J. (1986). The self-employment experience of immigrants. The Journal of Human resources., 21, 485-506. http://dx.doi.org/10.2307/145764

Boyatzis, R. E. (1998). Transforming qualitative information: thematic analysis and code development. Retrieved from http://aut.Iconz.ac.nz/vwebv/holdingsinfo?bibId=23287. Thousand Oaks, CA: Sage publications.

Boyd, M. (1989). "Family and Personal Network In International Migration: Recent Developments and New Agendas". International migration review,, 23(638-70). http://dx.doi.org/10.2307/2546433

Braun, V., \& Clarke, V. (2006). Using thematic analysis in psychology. Qualitative Research in Psychology, 3, 77-101. http://dx.doi.org/10.1191/1478088706qp063oa

Bryman, A. (2008). Social research methods (Third ed ed.). Oxford United Kingdom: Oxford University Press.

Bryman., A. (2009). Social Research Methods. New York: Oxford University Press.

Burnard, P., Gill, P., Treasure, E., \& Chadwick, B. (2008). Analysing and presenting qualitative data. British Dental Journal, 204(8). http://dx.doi.org/10.1038/sj.bdj.2008.292

Butcher, A., Spoonley, P., \& Trlin, A. (2006). Being accepted: The experience of discrimination and social exclusion by immigrants and refugees in New Zealand. New Settlers Programme Occasional Publication No 13, Palmerston North: Massey University.

Cain., T., Meares, C., Spoonley, P., \& Peace, R. (2011). Integration of Immigrants Programme. Massey University/University of Waikato.

Canada. (2011). Small business; minority owned business; opportunity; exports. Canadian Business, 84(17), $55,57,59,61$.

Choenni., A. (1997). Veelsoortig assortiment. Amsterdam: Het Spinhuis.

Collins, J. (2003). Australia: cosmopolitan capitalists down under. In Enow Carine Manyi (2010). Immigrant Entrepreneurship: Case studies of challenges faced by immigrant entrepreneurs in a large and small Swedish city. Jonkoping International Business School, Jonkoping University.

Daly, J., Kellehear, A., \& Gliksman, M. (1997). The public health researcher: A methodological approach. Melbourne, Australia:: Oxford University Press.

Daniel, J. D., Radebaugh, L. H., \& Sullivan, D. P. (2002). Globalization and business. New Jessey: Prentice Hall.

de Raijman, R. B. (1996). Pathways to self-employment and entrepreneurship in an immigrant community in Chicago. Illinois:: The University of Chicago.

de Vries, H. P. (2012). Do Indian immigrant entrepreneurs residing in different host countries display the same behavioural patterns? Journal of Enterprising Communities: People and Places in the Global Economy, 6(2), 138-153. http://dx.doi.org/10.1108/17506201211228949

Denscombe., M. (1998). The good research guide for small-scale social reseaerch project. Buckingham, United Kingdom: University Press.

Domboka., T. (2013). Entrepreneurial Experiences of 1st Generation Migrant Black African Female Entrepreneurs in Britain. Jaournal of Business Diversity, 12(1/2), 40-51.

Erica, A. (2013). History of Transracial Adoption: A New Zealand perspective. American Indian Quarterly, 37(1/2).

Fairlie, R. (2008). "Estimating the contribution of immigrant business owners to the U.S economy" U.S. Small Business Administration, Office of Advocacy, Washington D.C. www.sba.gov/advo.

Franck., A. (2012). Factors motivating women into micro-entrepreneurship in Malaysia. International Journal of Gender and Entrepreneurship, 4(1). http://dx.doi.org/10.1108/17566261211202981

Fregetto, E. (2004). Immigrant and ethnic entrepreneurship: a US perspective. In H. P. Welsch (Ed.), Entrepreneurship: The Way Ahead (pp. 253-268). New York: Routledge. http://dx.doi.org/10.4324/9780203356821.ch18 
Friese, S. (2014). Qualitative Data Analysis with ATLAS.ti. London: Sage publications.

Gaskill, L. A. R. S., Auken, V., Howard, E., \& Manning, R. A. (1993). A Factor Analysis Study of the Perceived Causes of Small Business Failure. journal of business management, 31(4), 18-33.

Gorter, C., Nijkamp, P., \& Poot, J. (1998). Crossing Boarders: Regional and urban perspectives on international migration.

Grinnell, R. M., \& Unrau, Y. A. (2005). Social work research and evaluation: quantitative and qualitative approaches. New York:: Oxford University Press.

Hofstede, G. (1991). Cultures and Organizations: Software of the Mind: Intercultural Cooperation And Its Importance For Survival. Great Britain: McGraw-Hill.

Hoselitz, B. (1964). Sociological Aspects of Economic Growth. New York: The Free Press of Glencoe.

Jones, T., McEvoy, D., \& McGoldrick, C. (2002). The economic embeddedness of immigrant enterprise in Britain. International Journal of Entrepreneurial Behaviour \& Research., 8(1/2), 11-31. http://dx.doi.org/10.1108/13552550210423697

Lee. (2003). The making of immigrant entrepreneurs: gendered processes of Korean small business ownership. New York: State University of New York.

Leung, M. (2002). From four course Peking duck to take-away Singapore rice. An inquiry into the dynamics of the ethnic Chinese catering business in Germany. Journal of Entrepreneurial Behaviour and Research, 8(1/2), 134-147. http://dx.doi.org/10.1108/13552550210423769

Li., P. S. (1997). Slef-Employment Among Visible Minority Immigrants, White Immigrants, and Native-Born Persons in Secondary and Tertiary Industries of Canada Canadian Journal of Regional Science, 22(1), 103-118.

Liargovas., P. G., \& Skandalis, K. S. (2012). Motivations of migrant entrepreneurship in Greece: a factor analysis approach. Journal of business and entreprise development, 19(4), 627-639.

London, G. (2005). The contribution of Asian-owned business to London economy. Greater London Authority www.london.gov.uk.

Massey, D. S., Arango, J., Hugo, G., Kauaouci, A., Pellegrino, A., \& Taylor, J. (1994). "An Evaluation of International M igration Theory: The north American Case" Population and Development Review, 20(699-751). http://dx.doi.org/10.2307/2137660

Masurel, E., Nijkamp, P., Tastan, M., \& Vindigni, G. (2002). Motivations and Performance Conditions for Ethnic Entrepreneurship. Growth and Change, 33(2), 238-260. http://dx.doi.org/10.1111/0017-4815.00189

Masurel., E., Nijkamp, P., \& Vindigni. (2004). Breeding places for ethnic entrepreneurs: A comparative marketing approach. Entrepreneurship and Regional Development., 16(1), 77-86.

Mata., R., \& Pendakur, R. (1999). "Immigration labour force integration, and pursuit of self-employment,". International migration review,, 33(2), 378-402. http://dx.doi.org/10.2307/2547701

Meares, C., Lewin, J., Cain, T., Spoonley, P., Peace, R., \& Ho, E. (2011). Bakkie, braai and boerewors: South African employers and employees in Auckland and Hamilton. Massey University/University of Waikato. Research report No.6

Metcalfe, H., Modood, T., \& Virdee, S. (1996). Asian self-employment: The interaction of culture and economics in England. London Policy Study Institute.

Min, P. G., \& Bozorgmehr, M. (2003). United States: The entrepreneurial cutting edge. In R. Kloosterman \& J. Rath (Eds.), Immigrant entrepreneurs: venturing abroad in the age of globalization (pp.17-37). Oxford: Berg.

Morgan, G. (2002). Departing Kiwi fuel immigration dilemma. . The National Business Review, 22.

Morrison, M., \& Moir, J. (1998). The role of computer software in the analysis of qualitative data: efficient clerk, research assistant or Trojan horse? Journal of Advanced Nursing, 28(1), 106-116. http://dx.doi.org/10.1046/j.1365-2648.1998.00768.x

Myers, M. D. (2009). Qualitative Research in Business Management. Thousand Oaks, California: Sage.

Myers, M. D., \& Newman, M. A. (2007). The qualitative interview in IS research: Examining the craft. . Information and Organization., 17(1), 2-26. http://dx.doi.org/10.1016/j.infoandorg.2006.11.001 
Nwajiuba., C. (2007). International migrants perception of some contemporary issues in migration: A study of Nigerian in Diaspora. Oxford Business and Economics Conference, Oxford University.

Okonta, P., \& Pandya, K. (2007). Entrepreneurial potentials of African-Caribbean in the United Kingdom. . Journal of Small Business \& Enterprise Development, 14(4), 702-718. http://dx.doi.org/10.1108/14626000710832785

Philip., M. (2001). International Migration and the European Union, Trends and Consequencies. European Journal on Criminal Policy and Research., 9(1), 31-49. http://dx.doi.org/10.1023/A:1011266119496

Pope, C., Ziebland, S., \& May, N. (2000). Qualitative Resaerch in Health Care: Analysing Qualitative Data. Department of Social Medicine, University of Bristol. http://dx.doi.org/10.1136/bmj.320.7227.114

Ram, M., \& Deakins, D. (1996). African-Caribeans in business. Journal of Ethnic and Mgration Studies,, 22(1), 67-84, DOI:10.1080/1369183X.1361996.9976522.

Rice, P., \& Ezzy, D. (1999). Qualitative research methods: A health focus. Melbourne, Australia:: Oxford University Press.

Richards, L. (2000). Using NVivo in Qualitative Research. London: Sage.

Richards., T. J., \& Richards, L. (1994). Using computers in qualitative research. In Y. S. Lincoln (Ed.), Handbook of qualitative research. CA: Sage Publications.

Sahin, M., Nijkamp, P., \& Reietdijk, M. (2009). Cultural diversity and urban innovativeness: personal and business characteristics of urban migrant entrepreneurs. The European Journal of Social Science Research,, 22(3), 251-281. http://dx.doi.org/10.1080/13511610903354364

Sasse., G., \& Thielemann, E. (2005). A research agenda for the study of migrants and minorities in Europe. Journal of common market studies, 43, 655-671. http://dx.doi.org/10.1111/j.1468-5965.2005.00590.x

Schmis, A. (2013). Migrant self-employment between precariousness and self-exploitation. www.ephemerajournal.org, 13(1), 53-74.

Teixeira, C. (2001). Community Resources and Opportunities in Ethnic Economies: A Case Study of Portuguese and Black Entrepreneurs in Toronto. Urban Studies, $38(11), \quad$ 2055-2078. http://dx.doi.org/10.1080/00420980120080934

Volery., T. (2007). Ethnic entrepreneurship: a theoretical framework. In L. Dana (Ed.), Handbook Of Research On Ethnic Minority Entrepreneurship (pp. 30-41). Cheltenham: Edward Elgar. http://dx.doi.org/10.4337/9781847209962.00009

Warren, C. D. (2003). An exploratory study of South African immigrant entrepreneurs in New Zealand. Research report (management), Massey University.

Whitehead., E., Purdy, D., \& Mascarenhas-keyes. (2003). Minority business in England; Report on the annual small business survey 2003 Ethnic boost. Small business sevice, 60/958.

Yeabsley, J. (1997). Settling policy issues in migrant choice of settlement. Wellington, New Zealand:. New Zealand Institute of Economic Research.

Yin, R. K. (1994). Case Study Research: Design and Methods (3rd ed.). London: Sage. 